\title{
Electoral Integrity: How Gerrymandering Matters
}

\author{
Sheila Suess Kennedy
}

If there has been a constant theme running through 2016 political campaigns, it is that the "system" is rigged and democratic processes no longer work. To the extent that culprits responsible for this state of affairs are identified, political activists on the Left (most prominently Bernie Sanders) point to money and the outsized influence of the $1 \%$, while those on the Right (most prominently Donald Trump) attack "political correctness," immigrants and minorities. Among members of the general public, dissatisfaction with the country's current direction is attributed to a wide number of additional grievances. One such grievance that has gained traction over the past several years is the perceived impact of state-level partisan redistricting, or gerrymandering, on both state and federal elections.

The public's widespread belief that gerrymandering is largely responsible both for "gaming the system," via the growth in the number of noncompetitive electoral districts and for current extremes of partisanship has revived efforts to reform the way in which states handle redistricting, and has reignited scholarly disputes over the degree to which the ills ascribed to partisan redistricting are accurate. At the same time, pending lawsuits challenging both redistricting practices and certain of those reforms will soon require the Supreme Court to revisit its redistricting jurisprudence.

Popular opinion would seem to weigh in on the side of those who argue that partisan redistricting has distorted the electoral process. (Li 2015, Hulse 2015, Draper 2012) Popular concern about the deleterious consequences of partisan redistricting is augmented by activism undertaken by think tanks and good government organizations, among them the Brennan Center, the League of Women Voters and Common Cause. Belief in the efficacy of partisan line-drawing is also exhibited by the political insiders who go to great lengths and significant expense to draw lines favorable to their electoral prospects. (Draper 2012)

It is thus timely to revisit not just the contending academic arguments about gerrymandering's influence on political polarization and partisan outcomes generally, but also the existing constitutional jurisprudence and especially the issue whether political rather than racial gerrymandering is justiciable, and if so, the appropriate standard to be applied. Redistricting reforms in states like California, Arizona and lowa have prompted efforts to revise redistricting processes in a number of other states, and cases pending before or on their way to the Supreme Court are poised to clarify the extent to which the Court will intervene in state redistricting decisions when partisan advantage, rather than race, is at issue. Finally, emerging analyses of the experiences of the states that have implemented reforms may provide evidence of the efficacy or lack thereof of redistricting reform, and confirm or fail to confirm the belief that such reforms can generate increased electoral competition, increase turnout, or decrease partisanship to any appreciable degree.

This article makes two arguments: first, that many of the data-driven conclusions of political scientists who dismiss the impact of gerrymandering - although accurate as far as they go-don't go far enough; that is, they ignore the extent to which redistricting may be implicated in the phenomena to which they

This is the author's manuscript of the article published in final edited form as:

Kennedy, S. S. (2017). Electoral Integrity: How Gerrymandering Matters. Public Integrity, 19(3), 265-273. https://doi.org/10.1080/10999922.2016.1225480 
do attribute the growth in the number of noncompetitive districts; and 2) the existence of a widespread public conviction that gerrymandering is undermining democratic legitimacy by depriving voters of voice has political consequences that may be difficult if not impossible to measure, but should not for that reason be dismissed as inconsequential. (As the Supreme Court noted in Shaw v. Reno, reapportionment is one area in which appearances do matter.)

\section{The Scholarship}

There is a copious scholarly literature dealing with gerrymandering, the practice of partisan redistricting that takes its name from then-governor of Massachusetts Elbridge Gerry. Over the years, scholars have disagreed about the actual impact of such practices. One group of researchers has argued that, although redistricting may matter at the margins, it is only one cause among many for the lack of competitiveness that characterizes state-level elections and elections for the U.S. House of Representatives. One of the most frequently cited authorities for the proposition that redistricting is not the primary cause of noncompetitiveness is a study by Abramowitz, Alexander and Gunning (2006). They tested three causal hypotheses: redistricting, partisan polarization and incumbency, and concluded that only the latter two were part of the "pattern of reinforcing advantages" that had led over the years to "extraordinarily uncompetitive" elections. They particularly noted the fundraising disparity between incumbents and challengers, although they did not consider the extent to which creation of safe seats via gerrymandering might contribute to that particular advantage of incumbency. Campbell and Jurek ( 2003) also attribute the decline of competition to the fundraising and other advantages enjoyed by incumbents.

Both political polarization and the lack of electoral competitiveness have been attributed to the growth of polarization between the states (Enten 2013), to geographical self-sorting (Wasserman 2014) and to single-member Congressional districts (Drutman 2016) rather than to gerrymandering.

A widely-cited article by McCarty, Poole and Rosenthal (2006) also dismissed the importance of gerrymandering to political polarization. (Finding "little evidence" for such a link, they did note that gerrymandering operates to increase Republican seat share in the House of Representatives, but concluded that this fact was not an important source of polarization.) However, their final paragraph is worth quoting, because it recognizes both the role of gerrymandering in reducing competition and the importance of public perceptions of legitimacy:

"Nothing we say should be interpreted as contentment with congressional districting as it is currently practiced. The protracted political and legal battles over the boundaries cannot help but diminish the legitimacy of American democracy. And redistricting does appear to have a negative value on electoral competition. There are many reasons to do something about gerrymandering. But reducing polarization is not one of them."

Other researchers and political figures have connected gerrymandering to both non-competitiveness and polarization. Carson, Crespin, Finocchiaro and Rohde (2007) concluded that redistricting is one among other factors producing polarization in the House of Representatives; former Congressman Lee Hamilton (2000) has written that the way in which congressional districts are drawn contributes to the

"overwhelming" advantages enjoyed by incumbents; and Sam Wang of Princeton's Program in Law and 
Public Affairs has statistically calculated the number of voters effectively disenfranchised by gerrymanders (Wang 2013). In 2006, Thomas Mann implicated gerrymandering in the polarization of the House of Representatives, and in a book co-authored with Norman Orenstein (2008), Mann argued that the decline in electoral competition and the entrenchment of partisan behavior has diminished incentives for compromise and bipartisan behaviors.

Interestingly, one of the most complete reviews of recent scholarly literature on the effects of partisan redistricting appears in an amicus brief filed by Mann and Orenstein on behalf of Arizona's independent commission in Harris v. Arizona Redistricting Commission. Mann and Orenstein are political scientists who have written extensively about redistricting, and about "packing" (creating districts with supermajorities of the opposing party) "cracking" (distributing members of the opposing party among several districts to ensure that they don't have a majority in any of them) and "tacking" (expanding the boundaries of a district to include a desirable group from a neighboring district). They cite to studies tying redistricting to the advantages of incumbency (Hirsh 2003, Issacharoff and Nagler 2007, Kang 2006, Levitt 2011), and also note that the reliance by House candidates upon maps drawn by state-level politicians operates to reinforce partisan rigidity.

Mann and Orenstein also cite to a 2009 article by Oedel, Lynch, Mulholland and Edwards, in which the researchers investigated whether representatives from districts drawn by independent commissions become less partisan.

"Contrary to the initial expectations of the authors, the evidence reviewed here suggests that politically independent redistricting seems to reduce partisanship in the voting behavior of congressional delegations from affected states in statistically significant ways.

There is a copious literature examining numerous other aspects of redistricting: questions of compactness and respect for communities of interest, the legal requirements imposed by various states, the mechanics of line-drawing, and especially the ways in which the mandates of the Voting Rights Act, both before and after its partial evisceration by the Court in 2013, interact with redistricting. Those issues are important, but ultimately tangential to the questions of competition, partisanship and perceived legitimacy considered here.

Whatever the scholarly doubts about the effects of partisan redistricting, a number of states are engaging in efforts to address the perception that district boundaries drawn as a result of political bias allow officeholders to choose their voters rather than the other way around, thus diminishing the integrity of the democratic process. The major challenge reformers face is the absence of judicial agreement on a standard of measurement that can be applied by mapmakers and courts to determine whether a given district's boundaries have been drawn so as to make them constitutionally improper.

\section{The Jurisprudence}

The question whether gerrymandering violates the Constitution did not arise until 1962, when the Supreme Court decided Baker v. Carr, often referred to as the "one person, one vote" decision. In Baker, Tennessee citizens eligible to vote brought suit to redress what they alleged was a deprivation of their federal constitutional rights. Under the terms of a 1901 statute, Tennessee had apportioned seats in the state's General Assembly and had subsequently failed to reapportion them, despite substantial growth 
in and redistribution of the State's population. The plaintiffs asserted that, as a result, they suffered a "debasement of their votes" and were denied the equal protection of the laws. Lower courts had dismissed the suit on the grounds that political reapportionment was not justiciable, but the Supreme Court reversed, holding that an apportionment case may be reviewed on Fourteenth Amendment grounds, so long as these grounds are independent from questions clearly assigned to political decisionmakers.

Subsequently, the Court has heard cases involving both racial and partisan gerrymandering; however, only two of those cases-Davis v. Bandemer and Vieth v. Jubelirer-focused exclusively on the issue of partisan redistricting. (A third case, League of American Citizens v. Perry (LULAC), challenged the propriety of a mid-decade redistricting in Texas, the only purpose of which, plaintiffs alleged, was to expand partisan advantage.)

In Davis v. Bandemer, Plaintiffs alleged that Indiana's Republican-controlled legislature had gerrymandered state legislative districts after the 1980 census.

The Court narrowly held claims of partisan gerrymandering justiciable under the $14^{\text {th }}$ Amendment's Equal Protection Clause, but found that the mere fact of an adverse effect on proportional representation (the discrepancy between the percentage of votes garnered by a political party and the number of seats that party ultimately won) was not a sufficient standard to demonstrate both partisan purpose and effect.

The problem identified by the Court was the lack of a reliable standard for determining when a district had been intentionally gerrymandered for partisan advantage. Justice White led a plurality of the Court in holding that plaintiffs would be required to prove both discriminatory intent and discriminatory effect, and that "unconstitutional discrimination occurs only when an electoral system is arranged in a manner that will consistently degrade a voter's or a group of voters influence on the political process as a whole" (at 132). The plurality's standard thus required evidence of continued frustration of the will of the majority or continued frustration of the ability of an identifiable minority to influence the political process. The Bandemer challenge lost because only one election had been held since redistricting.

As one legal scholar noted,

"In terms of a legal standard, requiring litigants to suffer a continued burden makes sense, as a single election cycle has too many variables to definitively show that gerrymandering caused the election outcome. Conversely, if there has been a constitutional violation, requiring litigants to continue to suffer the violation seems like a perverse result." (Butera 2015)

The standard applied by the plurality in Bandemer did not survive the Court's analysis in Vieth v. Jubelirer. In that case, Democratic voters challenged the legislative districts drawn by Republicans in Pennsylvania following the 2000 census. There was agreement that Justice White's standard was unworkable, but there the agreement ended. The four conservative judges argued that redistricting is a political question, and should not have been held to be justiciable; the four liberals argued that the Equal Protection Clause should apply; and Justice Kennedy disagreed with both positions. Kennedy rejected the Plaintiffs' gerrymandering claim, but also rejected the argument that the issue was nonjusticiable. The problem, for Kennedy, was the inability of litigants or members of the Court to devise a workable standard for determining whether a gerrymander had occurred. (Interestingly, the four 
Justices who believed the issue to be justiciable proposed three separate standards, none of which has been adopted.)

Even in $L U L A C$, where the highly irregular mid-decade redistricting would seem to be convincing evidence of a partisan motive, Kennedy found legitimate legislative objectives sufficient to uphold the validity of the new districts.

In the wake of LULAC, a number of social scientists and lawyers have tried their hand at devising a standard that the court-and especially Justice Kennedy-will see as workable. Two cases, the Arizona case previously discussed and another from Maryland, may offer the Court opportunities to consider two very promising efforts to fashion such a standard.

In "Partisan Gerrymandering and the Efficiency Gap," Stephanopolous and McGee (2014) proposed a standard incorporating the concept of "wasted votes." As Stephanopolous has described this standard, the efficiency gap is the difference between the parties' respective wasted votes in an election, divided by the total number of votes cast. "Wasted" votes are ballots that don't contribute to victory for candidates; they may be lost votes cast for candidates who are defeated, or surplus votes cast for winning candidates in excess of what they needed to win. When a party gerrymanders a state, it tries to maximize the wasted votes for the opposing party while minimizing its own, thus producing what Stephanopolous and McGhee call an efficiency gap. In a state with perfect partisan symmetry and no gerrymandering, both parties would have the same number of wasted votes. As a matter of simple arithmetic, the efficiency gap is equal to a party's undeserved seat share.

In their paper, Stephanopolous and McGhee go through several calculations based upon recent elections to demonstrate the relative simplicity and reliability of the efficiency gap.

Another proposed standard has been offered by Samuel Wang, in a paper for Princeton's Program in Law and Public Affairs (2015). Wang observes that identification of partisan asymmetry requires examining all of the districts in a state, and says "this is a job for statistics." In a New York Times op-ed explaining the approach developed in his paper (2016), Wang writes:

"An easy test is available that directly measures overall bias: the difference between the average and the median. This century-old statistic uses math that is in the Common Core standards for sixth grade. It also won this year's competition for a gerrymandering standard sponsored by the nonpartisan organization Common Cause."

The average-median difference is simple enough that a busy judge can calculate it in the margin of a brief. Here's how it works. First, calculate the targeted party's median vote share, which is defined as the middle district on a list that is sorted in order of increasing party vote share. If the targeted voters have been packed into a few districts, they are counted in the average but have little effect on the median. Thus, perhaps counter-intuitively, it is possible for more than half the districts to have a belowaverage number of partisan supporters.

Wang applied his standard to the Arizona district that is at issue in the case pending before the Supreme Court and concluded that the median Democratic vote share was less than the average by 3.3 percentage points, "a direction that slightly benefitted the Republicans....If the Commission was trying to show special favor to Democrats, it did a poor job." (In that case, Republicans are claiming that one of the districts drawn by Arizona's nonpartisan commission intentionally and unconstitutionally favored 
the Democrats. The Commission attributed the population discrepancy to requirements of the Voting Rights Act, and defended its magnitude as falling within allowable bounds, a defense with which Wang agreed.) In Wang's paper, he supplements this first statistical test with two others, and demonstrates that the tests can be used singly or in tandem, to determine the statistical likelihood of a particular outcome, that is, whether the outcome falls within or outside of what Wang calls "the zone of chance."

The Arizona challenge is to the state's use of an independent commission, and is unlikely to involve a direct consideration of potential standards. However, a case working its way to the Court from Maryland may offer an opportunity to directly evaluate the utility of various proposed standards. Shapiro $v$.

McManus challenged Democratic redistricting in that state. The District Court dismissed the challenge as insubstantial without convening a three-judge panel, despite the fact that the rules call for such a panel unless the case is "obviously frivolous." The Supreme Court reversed, finding that a three-judge panel should have heard the arguments. That ruling was procedural, and did not address the merits, but Court observers are cautiously optimistic about the case's potential to resolve the standards issue, because rulings by three-judge panels go straight to the Supreme Court, bypassing the usual appeals process. The Maryland case could thus give the Court its first opportunity in nearly a decade to revisit the issue of partisan gerrymandering.

Another case, from Wisconsin, is also in the pipeline, albeit further from Supreme Court consideration; in Whitford v. Nichol, Democrats are challenging a 2012 redistricting plan that they allege is the product of extreme gerrymandering, and they are relying upon the efficiency gap test to demonstrate the accuracy of that allegation. The District Court declined to dismiss the claims, despite noting that plaintiffs will face significant challenges proving their case.

\section{$\underline{\text { Reforms and Consequences }}$}

Over the past several years, a number of organizations and citizen groups have worked toward redistricting reform. In addition to the Brennan Center, the League of Women Voters and Common Cause, mentioned earlier, organizations like Fair Vote, End Gerrymandering, Ballotpedia, Redistricting Online, the National Council of State Legislatures, and the Public Mapping Project all maintain active and informative websites devoted to providing information and assistance to grassroots reform efforts.

Complicating these efforts is the fact that state redistricting procedures vary widely. Even the six states with independent commissions have varying membership requirements and procedural rules governing the establishment of boundaries for both state legislative and congressional districts. Although a number of other states have advisory commissions with varying degrees of input in the process, the six states that have thus far committed the redistricting process to independent commissions are Alaska, Arizona, California, Idaho, Montana and Washington.

Despite the continued insistence of many social scientists that gerrymandering is not a significant causal factor in non-competitive districts or political polarization, the early results of redistricting reforms have been salutary. This article has previously cited Oedel, Lynch, Mulholland and Edwards, who were surprised to find that redistricting reform moderated the partisanship of Representatives.

Stephanopoulos has found that the use of neutral institutions such as commissions produces fairer and more competitive elections. (DATE) In a 2008 study, Mark Dunkelman calculated that truly competitive 
House districts could generate up to eleven million additional votes, and that those votes would come disproportionately from states with particularly egregious gerrymandering practices. There is also emerging research supporting the proposition that redistricting reforms reduce the incidence of uncontested elections and increase the likelihood of a quality challenger entering the race (Cottrill 2012). At Lead or Leave, an Indiana Foundation formed to advance redistricting reform, lowa is held up as a success story; in the wake of its redistricting reforms, elections in that state have more closely reflected the actual partisan preferences of lowa voters (Zellner and Nierzwicki, 2014).

\section{Conclusion}

The scholarship may be contested, but if the numerous citizen organizations, editorials and letters to the editor are to be believed, the public is convinced that partisan redistricting is a major contributor to democratic dysfunction. It is difficult to quantify the extent to which perceptions of gerrymandering contribute to voter cynicism and apathy, but that difficulty does not justify dismissing the importance of those perceptions to political legitimacy.

In a 2012 paper delivered to the Western Political Science Association, James Cottrill made an important and frequently overlooked point: there are consequences of redistricting reforms that scholars have overlooked, because they are difficult or impossible to measure.

"In an era of heightened mistrust of government, there may be intrinsic benefits to redistricting reform that are not directly related to electoral outcomes, such as greater trust in government and increased political participation."

Marc Hetherinton (1998) has also assessed the importance and role of political trust in the electoral process.

If the Supreme Court accepts one of the proposed standards for evaluating whether a gerrymander has occurred, we may have the opportunity to find out whether those benefits are real, and if so, how extensive they may be. As this is written, pundits are attributing the appeal of extremism and support for "outsider" candidates in the 2016 election cycle to voter anger and frustration. To the extent that gerrymandering contributes to voters' cynicism, reforms that encourage more competition and less partisanship, while no panacea, couldn't hurt. 


\section{References}

Abramowitz, A., Alexander, B., \& Gunning, M. (2006). Incumbency, Redistricting and the Decline of Competition in U.S. House Elections. The Journal of Politics, 68, (1), 75-88.

Arizona State Legislature v. Arizona Independent Redistricting Commission, 576 U.S. (2015)

Baker v. Carr, 369 U.S. 186 (1962)

Butera, J. (2015). Partisan Gerrymandering and the Qualifications Clause. Boston University Law Review, 95, 303-334.

Campbell, J. E., \& Steve J. J. (2003). The Decline of Competition and Change in Congressional Elections. In Congress Responds to the Twentieth Century. Ahuja and Dewhurst, eds. (pp. 43-72) Columbus, OH: Ohio State University Press.

Carson, J.L., Crespin, M., Finocchiaro, C.J., \& Rohde, D.W. (2007). Redistricting and Party Polarization in the U.S. House of Representatives. American Politics Research, 35 (6), 878-904.

Cottrill, J. B. (2012, March) Non-Legislative Redistricting and the Public Trust: The Indirect Benefits of Electoral Reform. Paper presented at the 2012 Annual Meeting of the Western Political Science Association, Portland, OR.

Davis v. Bandemer, 478 US 109 (1986)

Draper, R (2012, October). The League of Dangerous Mapmakers. The Atlantic, http://www.theatlantic.com/magazine/archive/2012/10/the-league-of/309084/

Drutman, L. (2016, February 14). The clever strategy that could stop the polarization of American politics. Quartz. http://qz.com/615630/the-clever-strategy-that-could-stop-the-polarization-ofamerican-politics/

Dunkleman, M. (2008). Gerrymandering the Vote: How a 'Dirty Dozen' suppressed as many as 9 million voters. Democratic Leadership Council.

Enten, H. J. (2013) Why 'gerrymandering' doesn't polarize Congress the way we're told. The Guardian, http://www.theguardian.com/commentisfree/2013/jan/03/gerrymandering-polarise-congress

Hamilton, L. (2000) Noncompetitive Elections for Congress. The Center on Congress at Indiana University.

Hulse, C. (2016, January 25). Seeking to End Gerrymandering's Enduring Legacy New York Times, January 25, 2016. Retrieved from http://www.nytimes.com/2016/01/26/us/politics/seeking-to-endgerrymanderings-enduring-legacy.html?_r=0

Hetherington, M. J. (1998). The Political Relevance of Political Trust. The American Political Science Review, 92 (4), 791-808.

Hibbing, J.R. \& Theiss-Morse, E. (1995) Congress as Public Enemy: Public Attitudes Toward American Political Institutions. New York, NY: Cambridge University Press. 
Hursh, S. (2003). The United States House of Unrepresentatives: What Went Wrong in the Latest Round of Redistricting. Election Law Journal: Rules, Politics, and Policy, 2 (2), 179-216.

Issacharoff, S., \& Nagler J. (2007). Protected from Politics: Diminishing Margins of Electoral Competition in U.S. Elections. Ohio State Law Journal. 68, 1121-37.

Kang, M. S. $\backslash$ (2006). De-Rigging Elections: Direct Democracy and the Future of Redistricting Reform. Washington University Law Review, 84, 667-716.

League of American Citizens v. Perry, 548 US 399 (2006)

Levitt, J. (2011). Weighing the Potential of Citizen Redistricting. Loyola Law Review, 44 (2), 513-544.

Li, M. (2015 July 13). State Gerrymandering Reforms Start to Show Results. Retrieved from

https://www.brennancenter.org/blog/state-gerrymandering-reforms-start-show-results

Li, M. (2015 December 11). Could Partisan Gerrymandering Be Headed Back to the Supreme Court?

Retrieved from https://www.brennancenter.org/blog/could-partisan-gerrymandering-be-headed-backsupreme-court

Mann, T. (2006). Polarizing the house of representatives: how much does gerrymandering matter? In Brady, D. \& Nivola, P. Red and blue nation? Characteristics and Causes of America's Polarized Politics, (Vols. 1 pp. 263-282). Baltimore, M.D.: Brookings Institution Press.

Mann, Thomas and Norman Ornstein. Brief for Amici Curiae in Support of Appellees, Arizona State Legislature v. Arizona Independent Redistricting Commission. 2015.

Mann, T. \& Ornstein, N. (2012) It's Even Worse Than It Looks: How the American Constitutional System Collided with the New Politics of Extremism. New York, NY: Basic Books.

Mann, T. \& Ornstein, N. (2008) The Broken Branch: How Congress is Failing America and How to Get it Back on Track. New York, NY: Basic Books.

McCarty, N., Poole K.T., \& Rosenthal H. (2006). Does Gerrymandering Cause Polarization? American Journal of Political Science 53 (3), 666-680.

Oedel, D.G., Lynch, A.K., Mulholland, S.E., \& Edwards, N.T. (2009). Does the Introduction of Independent Redistricting Reduce Congressional Partisanship? Villanova Law Review, 54 (1), 57-90.

Opdycke, K., Segura, P. \& Vasquez, A.M. (2013). The Effects of Political Cynicism, Political Information Efficacy and Media Consumption on Intended Voter Participation. Colloquy, 9, 75-97.

Shapiro v. McManus, 577 US_ (2015)

Shaw v. Reno, 509 US 630 (1993)

Stephanopolous, N.O. (2013). The Consequences of Consequentialist Criteria. U.C. Irvine Law Review, 3, 669-715.

Stephanopolous, N.O. \& McGhee, E.M. (2015). Partisan Gerrymandering and the Efficiency Gap. University of Chicago Law Review. 82, 831-900. 
Vieth v.Jubelirer, 541 US 267 (2004)

Wang, S. (2015, December 05). Let Math Save Our Democracy. New York Times. Retrieved from http://www.nytimes.com/2015/12/06/opinion/sunday/let-math-save-our-democracy.html

Wang, S. (2013, January 02). Gerrymanders, Part 2: How Many Voters Were Disenfranchised? Retrieved from http://election.Princeton.edu/2013/01/02/gerrymanders-part-two-how-many-voters-weredisenfranchised/

Wang, S.S.-H., (2015) Three Tests for Practical Evaluation of Partisan Gerrymandering. Program in Law and Public Affairs and Princeton Neuroscience Institute, Princeton University. Advance online publication doi: http://guides.main.library.emory.edu/c.php?g=50081\&p=324328

Wasserman, D. (2013) Introducing the 2014 Cook Political Report Partisan Voter Index. Cook Political Report. Retrieved from http://cookpolitical.com/story/5604

Whitford v. Nichol (W.D. Wisconsin)

Wittman v. Personhuballah

Zellner, S. \& Nierzwicki, F. Drawing Lines in the Sand: Redistricting Commissions in the United States. Unpublished manuscript. School of Public and Environmental Affairs, Indiana University-Purdue University Indianapolis, Indianapolis, Indiana. 